\title{
TOPIC-BASED INSTRUCTION FOR TEACHING ENGLISH FOR YOUNG LEARNERS
}

\author{
Riryn Fatmawaty', Tiara Retno Haryani² \\ email: fatmawatyriryn@gmail.com; tiara.03march@gmail.com
}

\author{
Prodi Pendidikan Bahasa Inggris, Fakultas Keguruan dan Ilmu Pendidikan \\ Universitas Islam Lamongan
}

\begin{abstract}
This research is urgently developed to provide attractive model of teaching English for young learners. Referring to the elementary students' need on "represented" materials for English instruction which cover authenticity and the demand of need analysis, this study is conducted. Further topic-based instruction as the basis material is chosen since these materials are suitable with the need of the elementary students at primary or beginner level of learning. The materials are needed since the students should be "well introduced "with English as foreign language they require to master. In other words, the elementary students' interest in English will be determined by their first impression in English at school instruction, particularly with the materials (books) as the supplementary instruction in their classroom.

This research used descriptive qualitative design, which used questionnaire and interview as research instruments. The English instruction which is conducted in the elementary classroom using theme-based instruction aimed to achieve the following objectives: first, to raise the students at the beginner level interest and to reduce their fear of learning English. Second, to enhance the children's basis in English including the four language skills, grammar and vocabulary. The last is to provide a comfort and 'friendly' experience for the children to learn and practice their English. Finally, the result of this research is there are some topic chosen by students, that continually, the researcher arranged the prototype of materials as handbook of teaching. Students' responses are very good in topic-based instruction. According to them, they could felt enthusiast and interest to learn with the topic that they have chosen and knew.

Keyword: Topic-based instruction, English for Young Learner
\end{abstract}

\begin{abstract}
Abstrak
Penelitian ini pentingnya dikembangkan untuk memberikan model pengajaran bahasa Inggris yang menarik bagi pelajar muda. Mengacu pada kebutuhan siswa SD pada materi "penyajian kembali" untuk pengajaran bahasa Inggris yang mencakup keaslian dan permintaan analisis kebutuhan, maka penelitian ini dilakukan. Instruksi berbasis topik sebagai bahan dasar dipilih karena bahan ajar ini sesuai dengan kebutuhan siswa sekolah dasar pada tingkat pemula. Materi dibutuhkan karena siswa harus "diperkenalkan dengan baik" dengan bahasa Inggris sebagai bahasa asing yang mereka butuhkan untuk dikuasai. Dengan kata lain, minat siswa SD dalam bahasa Inggris akan ditentukan oleh kesan pertama mereka dalam bahasa Inggris di sekolah, terutama dengan materi (buku) sebagai instruksi tambahan di kelas mereka.

Penelitian ini menggunakan desain deskriptif kualitatif, yang mana menggunakan angket dan wawancara sebagai instrument penelitian. Instruksi bahasa Inggris yang dilakukan di kelas dasar menggunakan pengajaran berbasis tema yang bertujuan untuk mencapai tujuan berikut: pertama, untuk meningkatkan siswa pada tingkat minat pemula dan untuk mengurangi ketakutan mereka untuk belajar bahasa Inggris. Kedua, untuk meningkatkan basis anak dalam bahasa Inggris termasuk empat kemampuan bahasa, tata bahasa dan kosa kata. Yang terakhir adalah memberikan kenyamanan dan 'ramah' bagi anak-anak untuk belajar dan berlatih bahasa Inggris mereka. Akhirnya, hasil dari penelitian ini adalah ada beberapa topik yang dipilih oleh siswa, yang terus menerus, peneliti mengatur prototipe bahan sebagai buku ajar pengajaran. Tanggapan siswa sangat bagus dalam pengajaran berbasis topik. Menurut mereka, mereka bisa merasakan antusias dan minat untuk belajar dengan topik yang telah mereka pilih dan ketahui.

Kata kunci: Instruksi berbasis topik, bahasa Inggris untuk pelajar muda
\end{abstract}

\section{INTRODUCTION}

English learners at the primary level (approximately age's five to ten) are cognitively prioritized to acquire language skills in ways that lend themselves to an integrated skills and content-based, experiential approach. The teacher who understands the cognitive and social processes of second-language acquisition for teaching English for young learners is better equipped to help learners navigate the processes of classroom learning activities while also creating a fun, positive environment. In many cases, teaching English for young learner's teacher in English as a Foreign Language settings have a limited amount of time to accomplish their teaching goals and meet local requirements regarding the use of specific texts, tests, or other materials. A low-resource

\section{8 | Jurnal Kredo Vol. 1 No. 1 Oktober 2017}


environment can also pose challenges.

As we know, English is officially, become a local content in elementary school since 1994. In the implementation, there are so many problems that faced not only educator, but also material's developer. Teaching English for young learners requires special attention as well as the creativity in designing the materials development. Piccolo (2010) asserts that teaching English to young learners are not the same as giving instruction English to grown-ups or even teenagers. That is considered as the slip-up a considerable measure of educators makes when they confronted with overwhelming class of 3 to 5 years old. It becomes an insightful challenge for both educators and materials-developers. According to Kasihani K. E. Suyanto in book "English for Young Learner" one of important aims in teaching and English learning activity at elementary school is emerging children interest in learning English. To reach the aim, we need to realize children characteristics, so that we can choose the right method and the material for them.

In addition, young learners have plentiful energy to do some activities. They are enthusiastic in something, but uniquely ignoring something else. It is quicker to raise a child's motivation and enthusiasm than an adult's, but it is also easier to lose a child's motivation and enthusiasm than it is with an adult's (Simpson in Picollo, 2010). To activate and raise young learner's motivation, there are so many ways and treatments in doing this, based on the needs. One of them is by developing appropriate learning materials which reflected on their nature and characteristics.

Referring to the elementary students" need on "represented" materials for English instruction which coverauthenticity and the demand of need analysis, this study is conducted.Further topic-based writing as the basis material are chosen since, this materials are suitable with the need of theelementary students at primary or beginner level of learning.The materials are needed since the students should be "well introduced " with English as foreign language they require to master. In other words, the elementary students' interest in English will be determined by their first impression in English at school instruction, particularly with the materials (books) as the supplementary instruction in their classroom.

Based on the explanation above, the research is intended to answer the following three questions: 1).Do the children become more interested in learning English after being taught using topic-based instruction? 2). What are the children's perceptions of topic-based instruction? 3).Among the different topics in English instruction, which one do the children like most?

\section{REVIEW OF RELATED}

\section{LITERATURE}

\section{English to Young Learners}

Learning English as a second or foreign language will be more effective at primary level or at a young age. Young learners have more opportunities than adults. They are learning all the time without 
having the worries and responsibilities of adults. According to Sabilah (2004), learning foreign language is better at young age for the following reasons: (a). The brain is more adaptable before puberty than after and that acquisition of languages and cultures than adults, and that self-consciousness at an early age; (b).Children have fewer negative attitudes to foreign language $s$ and cultures than adults, an that consequently they are better motivated than adults; (c). children's language learning is more closely integrated with real communication because it depends more on the immediate physical environment than does adult language.

Meanwhile, Broughton, et al (2003) mentioned that the advantages of learning English in the early age are explained below: - Young children are still using their individual, innate language learning strategies to acquire their home language and soon find they can also use these strategies to pick up English; - Young children have time to learn through play-like activities. They pick up language by taking part in an activity shared with an adult; Young children have more time to fit English into the daily program. School programs tend to be informal and children's minds are not yet cluttered with facts to be stored and tested;-Young children who acquire language rather than consciously learn it are more likely to have better pronunciation and feel for the language and culture. Thus, children should be provided with some teaching materials which is suitable with their nature and characters. The students' need for

Young learners are categorized into two groups, they are

60 | Jurnal Kredo Vol. 1 No. 1 Oktober 2017 in the first level for five to seven years and for eight to ten years old includes to the second level which is belong to beginner because most of them study the foreign language in these age. In Indonesia those ages is in elementary school.

\section{The Characteristics of Elementary School Students}

The most important factor in teaching and learning in any setting is the learner. Learners of any age differ from one another in significant ways; individuals may learn best through listening or reading, they may learn more easily alone or within a small group, they may require heavy visual reinforcement or learn better trough verbal explanation, or they may respond better to a sequential or to a random organization of materials or experiences. Each learner's experiences differ from those of class peers in a variety of ways. Children and young adolescent, however, differ from older learners in certain patterned and predictable ways as they progress trough stages of development. An understanding of these general development characteristics is very important for the elementary and middle school language teacher.

Based on explanation above, more and more, the children in learning a foreign language at the earliest stages might be the different development and learning abilities in their language into abilities in English. The motor characteristics of a child are worthy of observation because they are indicators both of individuality and of maturity status. The characteristics of students in elementary school are different with secondary school, because 
secondary's teacher teach subject whereas elementary, teachers teach children. A discussion of the characteristics of any group must always run the risk of being misinterpreted.

Scoot (cited Arnold) p. 2-4 told about characteristic of students in elementary school, they are as follows:

- They are competence user of mother tongue

- Typical of elementary school students is curiosity.

- They need to inspect, to know, to organize, and to classify.

- They were expected to act as adults in every way, and they did so.

- They love to play and learn best when they enjoy themselves, but they also take themselves seriously and like to think that what they are doing is real work.

- They are enthusiastic and positive about learning.

- They rely on the spoken words as well as the physical word to convey and understanding meaning.

- Their own understanding comes through eyes, hands and ears.

Based on the characteristics of elementary school students above, the teachers have important role for elementary school students (Kenneth. T. Henson \& Delmar Janke:pp.22). The role of the teacher as follows:

- Making the children the center of learning.

- Encouraging children to use the freedom provider for them.

- Observing children so as to prepare the best possible environment, recognizing sensitive periods, and diverting unacceptable behavior to meaningful tasks.

- As teachers, we can capitalize on our students' natural curiosity and help them expand it by introducing them to new topics.

The teacher needs to remember that children may still find that English words as a foreign language is difficult to understand vocabulary well, it is an important think and basic of language. The children in learning a foreign language at the earliest stages might bring the different development and learning abilities in their first language into their abilities in English. For some students, especially telling time is a little bit difficult since they have to memorize.

\section{Teaching English to Young}

\section{Learners}

Teaching English to young learners is extremely different from teaching English to adult learners. Harmer (2001:37) shares his ideas concerning on teaching young learners based on age, learner differences, and motivation. First is the age. Age is a major factor in deciding about how and what to teach. People of different ages pose different needs, competences, as well as cognitive skills. There are few commonly beliefs about age. Some people say that children learn languages faster than adults do. Adolescences are believed unmotivated, surly and uncooperative and that therefore they make poor language learners. Otherwise, adults are having so many barriers to learning (both because of the slowing effects of ageing and 
because of their past experience) that they rarely have any success).

Second is the learner difference. Teaching children means teaching human being with all their differences. Therefore, to be successful in teaching children, teacher needs to consider differences brought by the learners. The differences can be in the form of aptitude, learner styles, language levels, and individual variations.

Third, the motivation Brown (2000), points out that a cognitive view of motivation includes factors such as the need for exploration, activity, simulation, new knowledge, and ego enhancement. The sources of motivation can be derived from many factors, namely society where live in, teacher, method, goal, setting, and learning environment.

In teaching English to young learners, in this case, the students of elementary school, the teachers must comprehend the concept of acquisition and learning. Acquisition can be defined as a process of having language naturally or subconsciously. On the other hand, learning is a process of having language consciously. Krashen and Terrell, (1983: 18) state that acquiring a language is 'picking it up', i.e., developing ability in language by using it in natural, communicative situations. Children acquire their first language, and most probably, second languages as well. Language learning is different from acquisition. Language learning is 'knowing the rules', i.e., having a conscious knowledge about grammar. According to recent research, it appears that formal language learning is not nearly as important in developing communicative ability in second languages as previously thought

In the teaching-learning process, the English teachers also must know the kinds of language learning resources for young learners, as follows:

a. Learning resources are not additional materials for pleasure but main materials which are ordered and learned as interesting activities which children usually do in their daily lives.

b. Learning resources for children must be appropriate for children's aptitude, will, world, and so forth. Therefore, ideal English teachers to young learners are those who are familiar with English songs and games in English. In addition, they are able to order those materials into becoming interesting ones.

c. There must be a clear distinction between technique and resource. Songs, stories, poems, and games are resources.

\begin{tabular}{llr}
\multicolumn{1}{c}{ Young } & learners, those \\
attending & preschool and \\
kindergarten, will not have any
\end{tabular} personal reason for studying English. It is simply another subject that they have to study at school or that their parents have told them they need to learn. At this point in their lives, they may not know or comprehend how important these classes can be. They might view your classes as simply another fun daily activity and that is just fine. Even at this early age, you can encourage them to develop an interest in learning English which will stay with them long after they have finished your classes.

Additionally, Inge Druckrey in article, "Teaching to See" said that as the teacher should to understand 
and teach young Learners Better. There are the ways:

\section{Teacher should to know what young learners want}

Student may be intimidating for some of the students in your class so, in order to encourage everyone to participate, it is important to make your lessons relaxed and fun. Young learner students will be learning very basic material but you can design creative lessons that get students moving around and speaking with one another. Young learners are generally very enthusiastic about songs, especially if they can sing along, and active games. Be sure to provide lots of encouragement and positive feedback. You want to create a safe, stress-free environment that everyone can enjoy learning in.

2. Teacher should to motivate how young learners behave

Keep exercises fun and short because these students have short attention spans and are easily distracted. Overacting and projection will help keep the focus on you. Teach students how to behave in a classroom by asking them to be quiet while you are talking and raise their hands if they have questions or want to answer a question. This may not be directly related to ESL but it is important that students learn good behavior early on; it will make their transition to primary school easier. Teach them to respond to basic classroom English phrases such as "Please sit down." because these are expressions that they will hear repeatedly throughout their study of English. For students at this age, you are responsible not only for starting to teach them English, but also for preparing them for their next level of education. Students will perform better in their classes if they behave well and have a good understanding of basic principles.

3. Teacher should to what focus on

The primary focus of these lessons will be on communication and laying a solid foundation for further English course work. Students should practice the different sounds of the English language and learn material such as the alphabet, numbers, colors and shapes. You will introduce vocabulary words gradually and may choose to study some simple structures that relate to everyday life too. It could be that reading and writing never enter into your classes but a focus on speaking and listening will help students become more comfortable and confident with English.

\section{Theme -based Instruction for}

\section{English Language Learners}

Indonesian government, The Minister of Education was gradually changing the education system from Curriculum 2006 to Curriculum 2013. One of differences between Curriculum 2013 with the previous one is the reduction of subjects taught in the classroom from ten to six. This happens because some subjects will be integrated to another which implies that Curriculum 2013 puts skill integration as its ultimate goal. To accommodate the demands of Curriculum 2013, Theme-Based teaching is assumed to be an appropriate approach to teach English to students in primary levels Theme-based teaching which is also termed theme-based instruction or topic-based teaching. It is one of the approaches within the broader model of context-based instruction in which 
the emphasis is on exposing students to a "highly contextualized" second language learning (Wesche \& Skehan, 2002, p.220). It is an approach to language teaching in which the whole course is structured around the certain themes or topics (Brinton, 2001; Brinton, Snow,Wesche, 2003). Theme-based instruction differs from traditional language instruction in that the language structures/items to be covered in a syllabus are determined by the theme or topic. The ThemeBased instruction itself has been practiced in UK primary classroom since 1960s (Cameron, 2001).

Theme-based instruction is an integral part of early language learning and provides an ideal environment for constructing meaning. In thematic teaching, the curriculum is organized around a thematic center, which can originate in the classroom, the school, the environment, or the target culture. Language concepts and concepts from the regular curriculum and the target culture are interrelated and presented as a whole, within a thematic framework. Language is tailored to the developmental level of the students; activities address a variety of learning styles and call forth a range of multiple intelligences. Students have many opportunities for identifying patterns and connections, experiencing engaging activities with emotional content, and interacting with their peers. It is the goal of the thematic instruction described in this book to reach every child with meaningful language and culture experiences.

In a theme-based course, different teaching activities are 64 | Jurnal Kredo Vol. 1 No. 1 Oktober 2017 integrated by their content, the teaching of different skill areas is incorporated into the theme (Brinton, Snow, \&Wesche, 2003), and "the theme or topic... acts as a connecting thread" (Cameron, 2001, p. 180) rationale for this thematic approach is to "avoid (s) fragmentation and unconnected skill exercises" and a variety of activities are integrated around meaningful context (Berry \&Mindes, 1993, p.6).

\section{Steps in Developing a Language Focused Theme-based Unit}

Shin and Crandall (2014) suggest five steps for a thematic unit designed over four to five lessons: 1). Choose topics that are relevant to the national curriculum standards of your context, 2). Select themes that appeal to the children in order to encourage meaningful and authentic interaction., 3). Employ subject content that is related to the children's experiences and based on the subjects they enjoy studying, for example, social sciences or on specific social situations, 4). Arrange the order of the activities to mirror real life language that is useful to the children The skills practiced should be sequenced from receptive to productive and progress from simple repetition to scaffold learning, and 5). Integrate a project into the unit to foster student-centered learning, cooperation and communicative use of the target language.

The followings are briefly described some steps in developing language focused theme-based unit (Enright, D. Scott and McCloskey, Mary Lou (1988): First, expressing the chosen theme such as : a). Interaction activity which has oral interaction as its focus; b). experiential activity, which centers around an out of class experience; c). grammar-focused activity, which 
focuses on indirect use of an aspect of English structure; d). writing activity; total physical response activity, which follows prescribed procedure; f) reading; g) listening; h) problem-solving activity; and i) games. Secondly, in developing a vocabulary list, the list of words should be appropriate to the theme. This means the relationship between the themes should be relevant. Thirdly, the activities are written in sequence. It is important to determine which activities are appropriate for promoting concept and vocabulary attainment. Finally, the implemented activities are necessary to be continuously revised for future use.

Figure 1.Chart Activities

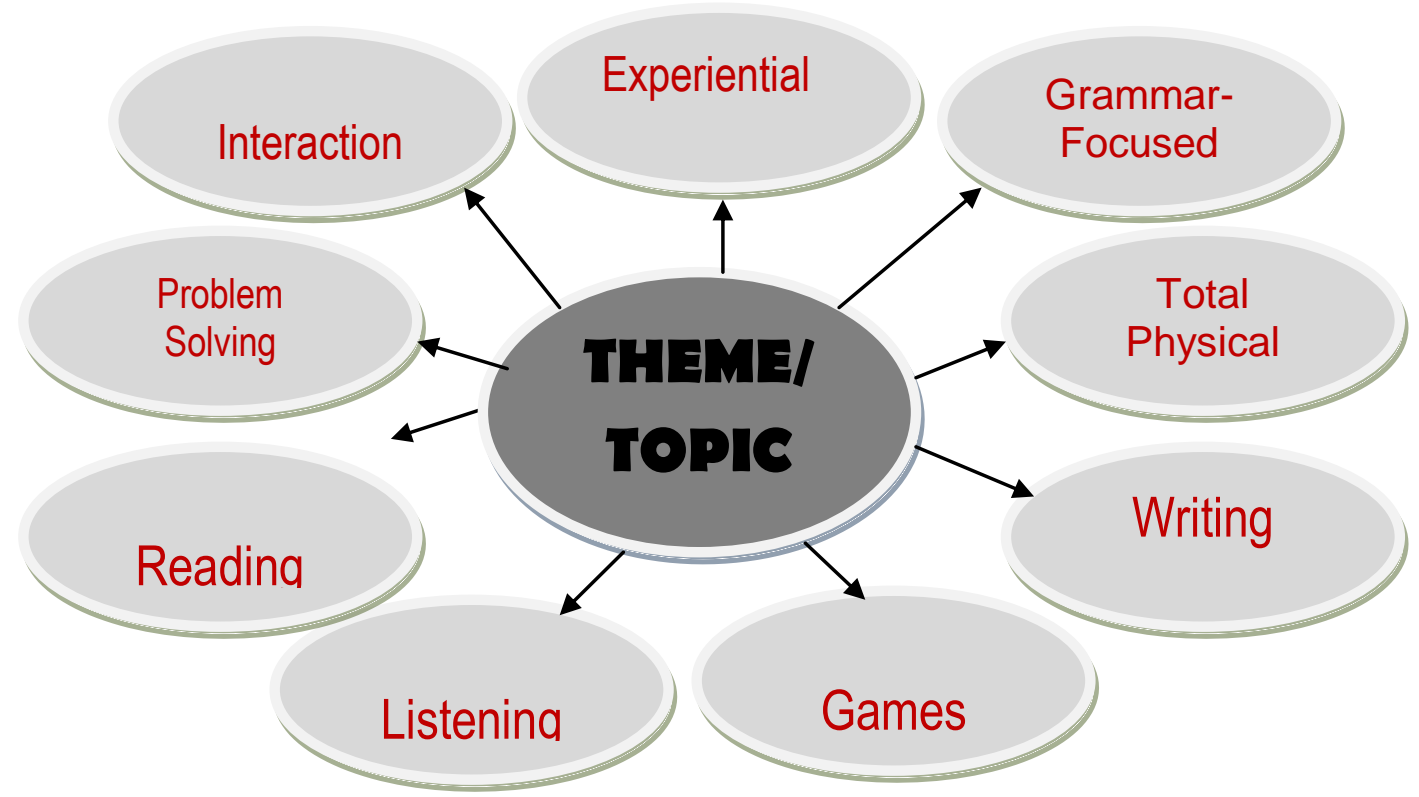

The detail's explanations of nineactivities:

1. Interactive: example; Students in pairs or small groups list items found under each of five illustrated headings: boxes, cans, bottles, bags, jars.

2. Experiential: example;

Students prepare for and are assigned tasks, observe and record during ihe visit, and process the visit through discussion and writing. $\underline{P}$

3. Grammar-focused: example; Students have a list of different foods. They ask each other questions using the construction "Have you ever eaten.. .?"(e.g., "Have you ever eaten cous-cous?") and write down the names of individuals who answer "yes".

4. Writing: example; In pairs, students interview, then write a paragraph about why Lheir partner does not like or eat a type of food very often.

5. Total Physical Response: example; After watching a demonstration of how to 
prepare a particular food, students imitate the proccss.

6. Reading: Students read a list of food price ads from two supermarkets and compare the costs by answering "yes" or "no" to true-false statements.

7. Listening: example; Students make up an ending to a story about how tomatoes were considered poisonous.

8. Problem-solving: example; from a series of food pictures, each with prices, students list what they would have for breakfast, lunch, and dinner. With $\$ 20$ students go "shopping", choosing foods that cost $\$ 20$ or less.

9. Game: example; Students circle food words hidden in assorted letters.

\section{RESEARCH METHOD}

This study used descriptive qualitative design. Conducting this research is aimed to achieve the following objectives: first, to raise the students at the beginner level interest and to reduce their fear of learning English. Second, to enhance the children's basis in English including the four language skills, grammar and vocabulary. The last is to provide a comfort and 'friendly' experience for the children to learn and practice their English.

This research conducted in July-September 2017. in MI Babul Ulum Dorogede Gedangan. The participants of the study are students of Elementary School MI Babul Ulum. It is consists of 25 students with eight and ten years old that included in third, fourth and sixth grade that chosen randomly. This school is categorized as average school with average Standard of achievement. This school is located in remote area with inadequate infrastructure. The students' genuine character and their origin behavior are required to know how the instructional materials could significantly assist the students in learning English.

\section{Instruments and Procedures}

The students are enrolled in the English course/instruction using topic-based instruction. Also the researchers will be asked and to sign an informed consent form to make sure that they understood the purpose and procedures of the study.

The pre-course questionnaires will be distributed to the students to explore their initial interest in English. Meanwhile, at the end of the whole course/instruction, the postcourse questionnaires will be distributed to investigate if the children had become more interested in learning English, and to examine their perceptions of theme-based instruction adopted in the English instruction and their opinions of the themes chosen for the course. The question items in both the pre-and post-course questionnaires are made in bilinguals so that the students could understand the items easily.

The second instruments used are semi-structured interviews. They are conducted with the students Three to four students will be randomly selected and interviewed made in small groups to get the greater depth and richness of information (McMillan, 2004, p. 167) concerning with theme-based instruction students had experienced with. All the questionnaires and interviews are conducted in Indonesian so that the children could 
easily understand the researchers' questions and express their opinions easily without any obstacles or language barriers. Further, the interviews are audio recorded, transcribed, and analyzed qualitatively to identify the main the main themes using a grounded theory study. A coding paradigm will be used in which central themes were generated and a theory could then be developed.

\section{RESULT \& DISCUSSION}

In the section 1 of this research, the pre-course questionnaires distributed to the 25 students to explore their initial interest in English. The result of prequestionnaire is:

Figure 2.Questionnaire for Students' Responses on English Learning in the School

\begin{tabular}{|c|c|c|c|c|c|}
\hline \multirow[t]{2}{*}{ No } & \multirow[t]{2}{*}{ Item of Questionnaire } & \multicolumn{4}{|c|}{ Total of Students' choices } \\
\hline & & $\mathrm{S}$ & SS & TS & STS \\
\hline 1. & Belajar bahasa Inggris itu mudah & 10 & 2 & - & 13 \\
\hline 2. & Belajar bahasa Inggris di kelas sangat menyenangkan & 20 & 3 & 2 & - \\
\hline 3 & Materi bahasa Inggris di kelas sangat menarik & 12 & 7 & 2 & 4 \\
\hline 4.. & Metode belajar bahasa Inggris di kelas sangat atraktif & 4 & 2 & - & 19 \\
\hline 5. & Guru bahasa inggris di kelas sangat ramah dan baik hati & 7 & 16 & 2 & - \\
\hline 6. & Guru bahasa inggris memberikan tugas dan mengevaluasinya & 20 & 3 & - & 2 \\
\hline
\end{tabular}

We can see that those students like on learning English but they feel it so difficult. Their teacher is humble in kind but they feel method that used in the class is not attractive although they feel learning English is very interesting. It means that actually, English is interesting for our young students/learners if the method that teacher uses can attract them by fun and attractive learning. Then, in Section 2, the children are required to place the themes chosen for the English course in a rank order.

Figure 3. Chosen Themes for English Course

\begin{tabular}{lc}
\hline \multicolumn{1}{c}{ Tema/Topik } & Beri tanda $(\sqrt{ })$ untuk tema/topik yang kamu suka \\
\hline House & 10 \\
\hline Technology & 7 \\
\hline Toys & 10 \\
\hline Number & 5 \\
\hline Animal & 19 \\
\hline
\end{tabular}




\begin{tabular}{lc}
\hline Food & 25 \\
\hline Family & 23 \\
\hline Friend & $\mathbf{1 0}$ \\
\hline School & $\mathbf{1 0}$ \\
\hline Profession & $\mathbf{1 7}$ \\
\hline
\end{tabular}

From figure 2, the rank order of topic that chosen by students, rank 1 is food, rank2 is family, rank 3 is animal and for last rank is profession. Based on this data, the researcher made lesson plan using the topics chosen as the last activity of the research that is as prototype arranged for teaching English for young learner

For section 3, is the postcourse questionnaires was distributed to investigate if the students are more interest in learning English, and to examine their perceptions of themebased teaching adopted in the English course and their opinions of the themes chosen for the course. The question items in both the preand post-course questionnaires were bilingual so that the children could understand the items easily. Same with Section 1, in section2, all the question items are in a 4-point Likert Scale, ranging from 'Strongly agree' to 'Strongly disagree' ( 4 = 'Strongly agree'; 3 = 'Agree'; 2 = 'Dis-agree'; $1=$ 'Strongly disagree'). A 'Neutral' option is avoided because Busch (1993) mentions that "neutrality can lead to indecisive data, particularly among those groups whose cultures value indirect responses" (p. 735). s.

Figure 4.Questionnaire of Students' Responses on Topic-based Instruction

\begin{tabular}{|c|c|c|c|c|c|}
\hline \multirow[t]{2}{*}{ No } & \multirow[t]{2}{*}{ Item of Questionnaire } & \multicolumn{4}{|c|}{$\begin{array}{l}\text { Total of Students' } \\
\text { choices }\end{array}$} \\
\hline & & $\mathrm{S}$ & $\mathrm{SS}$ & $\mathrm{TS}$ & STS \\
\hline 1. & Belajar Bahasa Inggris berbasis topik lebih menyenangkan & 19 & 6 & - & - \\
\hline 2. & Belajar Bahasa Inggris berbasis topik lebih efektif & 11 & 7 & 7 & - \\
\hline 3 & Belajar Bahasa Inggris berbasis topik lebih atraktif & 13 & 6 & 6 & - \\
\hline 4. & Siswa lebih semangat belajar bahasa Inggris berbasis topic & 16 & 6 & 2 & - \\
\hline 5. & Saya lebih kreatif belajar bahasa Inggris berbasis topic & 14 & 6 & 5 & - \\
\hline 6. & $\begin{array}{l}\text { Saya lebih mudah memahami materi dengan belajar bahasa Inggris berbasis } \\
\text { topik }\end{array}$ & 14 & 6 & 5 & - \\
\hline 7. & $\begin{array}{l}\text { Saya lebih mudah menguasai materi dengan belajar bahasa Inggris berbasis } \\
\text { topik }\end{array}$ & 16 & 4 & 5 & - \\
\hline 8. & $\begin{array}{l}\text { Saya lebih mudah mengingat materi dengan belajar bahasa Inggris berbasis } \\
\text { topik }\end{array}$ & 16 & 4 & 5 & - \\
\hline 9. & $\begin{array}{l}\text { Saya mampu mempraktekkan materi di kelas dengan belajar bahasa Inggris } \\
\text { berbasis topic }\end{array}$ & 16 & 4 & 5 & - \\
\hline
\end{tabular}

68 | Jurnal Kredo Vol. 1 No. 1 Oktober 2017 
It means that, students or learners perceptions are more interest and spirit learning English by using topic that they have chosen. The questionnaires are collected immediately by either the researcher, or the course tutors, when the children finished completing them.

A part from the questionnaires, semi-structured interviews conducted with the students. Three to four children were randomly selected from each centre (depending on the total number of children in a certain centre) and interviewed in small groups so that "greater depth and richness of information" (McMillan, 2004, p.
167) about their perceptions of the English course and the themes could be obtained, and they would feel less threatened in answering the interviewer's questions. All the questionnaires and interviews will be conducted in Bahasa Indonesia so that the children could understand the researcher's questions and express their opinions easily, without any language barrier. The interviews used audio recorded, transcribed and analyzed qualitatively to identify the main themes using a grounded theory study. A coding paradigm is used in which central themes are generated and a theory could then be developed (McMillan, 2000).

Figure 5.Interview's Items to Students on English Learning in the School

Pertanyaan 1.Apakah adik menyukai pelajaran bahasa Inggris? Kenapa?

Pertanyaan 2.Apakah guru bahasa Inggris adik di sekolah ramah dan baik?

Pertanyaan 3.Bagaiman metode belajar bahasa Inggris di kelas?

Pertanyaan 4.Jenis buku pelajaran apa yang pakai di kelas?

Pertanyaan 6. Kira-kira tema/topik tentang apa saja yang adik sukai dalam belajar bahasa Inggris

\section{CONCLUSION}

Finally, the result of this research is there are some topic chosen by students, that continually, the researcher arranged the prototype of materials as handbook of teaching. Students' responses are very good in topic -based instruction. According to them, they could felt enthusiast and more interest to learn with the topic that they have chosen and knew. Topic-based instruction that consist nine activities not only focuses on four skills. Such as; interaction activity, experiential activity, grammar-focused activity, writing activity; total physical response activity, reading, listening, problemsolving activity, and games. All of activity arranged, analyzed, and presented in lesson plan as prototype to teaching English for young learners by the topic that they have chosen. Fortunately, the student can make connections between what they know and what are they learning. Finally, topic-based instruction presents a variety of content-related activities through which learning can be accomplished. 


\section{REFERENCES}

Arntsen, Tara. "How To Teach Young Leamers: One Step At A Time". In www.busyteacher.org/4261-how-to-teach-young-learners-one-step-at-a-time.html..

Arnold G, M.D. and Frances L. ILG, M.D., The Child from Five to Ten, (New York: Harper

and Brother Publisher)

Berry, C.F., \&Mindes, G. 1993.Planning a theme-based curriculum: Goals, themes, activities, and planning guides for $4^{\text {th }}$ and $5^{\text {th }}$. Glenview, IL: Good Year Books.

Brinton, D.M. 2001. A theme-based literature course: Focus on th city of angels. In J. Murphy \& P. Byrd (Eds), Understanding the courses we teach: Local perspective on English Language Teaching (pp. 281-308) Ann Arbor. The University of Michigan Press.

Brinton, D.M., Snow, M.A., \&Wesche, M. 2003. Content-based Second Language Instruction. Ann Arbor: The University of Michigan Press.

Broughton, G., Brumfit, C., Flavell, R., \&Pincas, A. 2003. Teaching English as a Foreign Language (second edition) NY.

Brown, H.D. 2000.Principles of Language Learning and Teaching. Fourth Edition. Pearson Education Ltd.

Busch, M. 1993. Using Likert Scales in L2 Research .TESOL Quarterly, 27 (4).

Cameron, L. 2001. Teaching Languages to Young Learners. Cambridge: Cambridge University Press.

Enright, D. Scott and McCloskey, Mary Lou (1988). Integrating English.

Reading, MA; Newbury House Publishe

Harmer, J. 2001.The Practice of English Language Teching. $3^{\text {rd }}$ Edition. Pearson Education Ltd.

Kenneth. T. Henson and Delmar Janke. 1984, Elementary Science Methods, ( USA : McGraw-

Hill,Inc.,

Krashen, Stephen D. and Terrell, Tracy D. 1983. The Natural Approach, New Jersey: Alemany Press Regent/Prentice Hall.

70 | Jurnal Kredo Vol. 1 No. 1 Oktober 2017 
McMillan, J.H. 2000.Educational Research: Fundamental for the Consumer. $3^{\text {rd }}$ Edition. New York: Longman.

McMillan, J.H. 2004.Educational Research: Fundamental for the Consumer. $4^{\text {th }}$ Edition. Boston, mass: Pearson/Ally and Bacon

Sabillah, F. 2004. Teaching English to Young Learners: Its Policy, Framework, and Activity.Pearson Education Ltd. UM Press.

Scoot, Wendy. 1990. Teaching English to Children,(Newyork: Longman)

Suyanto, Kasihani K. E. 2007. English for Young Learners. Jakarta: Bumi Aksara

Wesche, M.B., \&Skehan, P. 2002. Communicative, task-based, and content language instruction.In R.B. Kaplan (Ed), The Oxford handbook of Applied Linguistics.NewYork: oxford University Press. 